\title{
Our Hungry Planet
}

\author{
M. H. Saier Jr. • J. T. Trevors
}

Published online: 17 June 2008

(C) Springer Science + Business Media B.V. 2008

The recipe for an increasingly hungry planet is simple. Take a human population of 6.6 billion, and let it increase at a rate of about 75 million annually. Pollute the biosphere to produce accelerated climate change, and consume an increasing amount of fossil fuels annually without switching to nonpolluting forms of renewable energy. Divert grain crops to the manufacture of biofuels, increase grain prices and food shortages, and you have the perfect recipe for a hungry planet. Remember, only rice, wheat and corn stand between humans and starvation, and over 40 conflicted countries in Africa, Asia, Latin America and Europe are already facing disastrous food shortages. What's worse, the prices of some grains worldwide have increased over $100 \%$ in the past year alone.

Resource shortages are intertwined with complex events such as civil strife, displacement of human populations and refugee movements. Additionally, droughts, extreme weather conditions such as floods and cyclones increase in frequency and severity as a result of current human activities. Finally, governmental and private corruption, civil wars and other

M. H. Saier Jr.

Division of Biological Sciences,

University of California, San Diego,

La Jolla,

San Diego, CA 92093-0116, USA

e-mail: msaier@ucsd.edu

J. T. Trevors $(\triangle)$

Department of Environmental Biology,

University of Guelph,

Guelph, ON, Canada NIG 2W1

e-mail: jtrevors@uoguelph.ca conflicts contribute to poverty. The consequence is that food production lags behind population growth causing continually increasing food prices, even though many people around the world cannot afford the current prices. In reality, this means that millions more people will face the risk of insufficiency and starvation than is currently the case.

The United Nation estimates that about 73 million people in 78 countries depend on the United Nations World Food Programme to avoid starvation. Moreover, there is also an increasing demand for food in China and India, countries that are experiencing immense economic growth. Even worse, in India and most under-developed countries, the human population is increasing out of control. This uncontrolled reproduction deprives poorer women worldwide of their freedom of choice and sacrifices our hope for a state of well being for future generations.

The worldwide shortage of food is also caused by farmland being developed for housing. There is only so much plant genetics can do improve the quality and quantity of food crops, and we may have already reached the limits of genetic engineering potential. Our worldwide grain reserves are now down to the lowest level in 30 years. The hopes of a "green revolution" need to be abandoned, and in its place, we need a rational approach that recognizes the limits of our planet.

Agriculture requires immense amounts of water, and drought conditions are increasingly occurring in numerous parts of the world where desertification continues its progression. What can we do today to help solve the food shortages that plague us now and will be increasingly problematic in the future? Some 
solutions include water and energy conservation and less emphasis on animal protein. However, universal human birth control and abortion services, paid for by the more affluent nations, are probably our best investment. Research and development would be a second essential investment for long-term solutions to our current and yet-to-be recognized problems, some of which cannot be foreseen. Still another worthwhile investment would be universal education, especially for women, so they, and everyone worldwide, can recognize the critical period of need we are entering. If rational well-informed thought cannot serve as our guide for careful planning, then there is no hope for future generations.

One final factor that greatly contributes to resource depletion, misery and premature death is armed conflict. International bodies such as the UN must be strengthened until they have the power to control greedy personal and national motives that strive to gain more than their share of resources through the use of military action. Nationalism is out-dated; we cannot continue to make the mistakes of the past. International cooperation and assistance is our only hope.

With current food shortages and increasing food costs already at a crisis level for hundreds of millions of people, why do we not make universal birth control our top priority? Religious and cultural excuses for allowing overpopulation are simply not acceptable.
We need rational solutions based on science. Further human reproduction and population expansion means further species extinction and the loss of our biospheric life support system. It means increased suffering.

All organisms are genetically programmed to reproduce. However we must use wisdom and rational behavior to produce a human population that does not destroy our common biosphere. Any program that leads to an increase, rather that a decrease in human suffering is not acceptable. 6.6 billion people are already far too many people for our hungry planet to maintain sustainable with acceptable life styles. Any attempts to solve the global climate change disaster will be thwarted without universal birth control.

Why would poor parents continue to have multiple children when they cannot sustain and care for their offspring? The answer is, that very few want them; they just don't know how to prevent these new arrivals while still satisfying their basic biological needs. Thus, illogical, irrational behavior must be prevented at all levels. At the level of the family, at the level of the community, at the level of nations, and at the level of the international community. Proper education and proper women's health provision MEANS provision of universal birth control. This would be the first and most important step towards satisfying the needs of our hungry planet. 